\title{
Fruit and vegetable intake: vitamin $C$ and $\beta$-carotene intake and serum concentrations in six-year-old children and their parents
}

\author{
I. Thorsdottir', I. Gunnarsdottir', S. E. Ingolfsdottir' and \\ G. Palsson ${ }^{2}$
}

'Unit for Nutrition Research, Landspitali-University Hospital, and Department of Food Science, University of Iceland, Reykjavik, Iceland; ${ }^{2}$ Children's Hospital, Landspitali-University Hospital, and Faculty of Medicine, University of Iceland, Reykjavik, Iceland

Abstract

Background: Intake of fruit and vegetables, which are important sources of antioxidant nutrients, has frequently been inversely related to the risk of chronic diseases.

Objective: To investigate the serum concentration of vitamin $\mathrm{C}$ and $\beta$-carotene in relation to fruit and vegetable intake in 6-year-old children and their parents.

Design: An observational study on families of healthy 6-year-old children in the Greater Reykjavik area. Serum vitamin $C$ and $\beta$-carotene were analysed. Fruit and vegetable intake of children and their parents was assessed by 3 day weighed food records and by a food frequency questionnaire.

Results: A positive correlation was seen in serum vitamin $\mathrm{C}$ concentration $(r=0.454-0.570, p<0.005)$ and serum $\beta$-carotene concentration $(r=0.385-0.497, p<0.02)$ between family members. The total intake of fruit, vegetables and fruit juice was $164 \pm 124 \mathrm{~g}$ (mean \pm SD), $302 \pm 181 \mathrm{~g}$ and $238 \pm 175 \mathrm{~g}$ for children, mothers and fathers, respectively. Family members' intake of fresh fruit, fruit juice and green leafy vegetables was positively related $(r=0.227, p<0.02$ and $r=0.313, p<0.01$ between children and their mother and father, respectively, and $r=0.247, p<0.05$ between parents).

Conclusions: The relationship between children's and their parents' fruit and vegetable intake is supported in the present study by an even stronger correlation of serum vitamin $C$ and $\beta$-carotene between family members. Interventions aimed at increasing fruit and vegetable consumption by children should focus on the whole family.

Keywords: antioxidants; child; fruit; nutrition; parent-child relationship; vegetables

Received: 20 Jan. 2006; Accepted: 25 Apr. 2006

\section{Introduction}

Fruit and vegetable intake has frequently been inversely related to the risk of chronic diseases (1$3)$. Fruit and vegetables are important sources of antioxidant nutrients and consumption has been positively correlated with serum vitamin $\mathrm{C}$ and carotenoids (4-6). Vitamin $\mathrm{C}$ and $\beta$-carotene are known to be powerful antioxidant nutrients. Via their antioxidant functions of protecting organisms against free radical damage, vitamin $\mathrm{C}$ and $\beta$ carotene may play a helpful role in the prevention of diseases initiated or promoted by oxygen radicals, such as cardiovascular diseases and cancers (7).
In the context of the rising burden of chronic diseases, the World Health Organization (WHO) aims actively to promote increased consumption, production and distribution of fruit and vegetables, and has recommended an intake of a minimum of $400 \mathrm{~g}$ of fruit and vegetables per day for adults (8). Although the mean intake of fruit and vegetables has been increasing among adults in Iceland the past few decades (9), the intake is still below the recommended level. For successful interventions to increase fruit and vegetable consumption further, knowledge is needed about the relationship between intake by parents and their children of fruit and vegetables. 
The aim of this study was to investigate the association of fruit and vegetable intake between 6year-old children and their parents, and to explore further the relationship between serum concentrations of vitamin $C$ and $\beta$-carotene and fruit and vegetable intake.

\section{Methods}

\section{Subjects}

Families of 6-year-old children from two random cohorts, of a longitudinal study on infant nutrition in Iceland (10) and a study of Icelandic 2-year-olds (11), were invited to participate in the study on the nutrition and health of Icelandic 6-year-olds $(n=$ 188). In total, 131 children $(70 \%)$ successfully completed a 3 day dietary record. Parents were asked to complete a food frequency questionnaire (FFQ). The participation rate was better among mothers $(n=112)$ than fathers $(n=75)$.

For practical reasons, only those families living in the Reykjavik area were invited to participate in blood tests for measurements of serum vitamin $\mathrm{C}$ and $\beta$-carotene. The number of family members participating in this part of the study is shown in Table 1.

The local ethics committee at the LandspitaliUniversity Hospital in Iceland and the Icelandic Data Protection Commission approved the study.

\section{Blood samples and analysis}

Consent was obtained from both parents and children before their participation in giving blood samples. Each child was given two EMLA (Albertslund, Denmark) band-aids medicated with anaesthetic (lidocaine, prilocaine), to anaesthetize the area from which blood would be drawn. Venous blood samples were drawn from the children using

Table I. Serum concentrations of vitamin $\mathrm{C}\left(\mu \mathrm{mol} \mathrm{I}^{-\mathrm{I}}\right)$ and $\beta$-carotene $\left(\mu \mathrm{mol} \mathrm{I}^{-1}\right)$

\begin{tabular}{|c|c|c|c|c|}
\hline & $n$ & Mean $\pm S D$ & 10th \% & 90 th \% \\
\hline \multicolumn{5}{|l|}{ Child } \\
\hline Vitamin C & 78 & $74.3 \pm 20.8$ & 47.1 & 102.9 \\
\hline$\beta$-Carotene & 83 & $0.5 \pm 0.3$ & 0.2 & 0.8 \\
\hline \multicolumn{5}{|l|}{ Mother } \\
\hline Vitamin C & 58 & $55.2 \pm 19.8$ & 30.4 & 82.3 \\
\hline$\beta$-Carotene & 61 & $0.4 \pm 0.3$ & 0.2 & 0.6 \\
\hline \multicolumn{5}{|l|}{ Father } \\
\hline Vitamin C & 31 & $47.5 \pm 17.9$ & 25.3 & 74.3 \\
\hline$\beta$-Carotene & 31 & $0.3 \pm 0.2$ & 0.1 & 0.5 \\
\hline
\end{tabular}

four $4.7 \mathrm{ml}$ gel serum vials, $1.2 \mathrm{ml}$ EDTA vials and two $4 \mathrm{ml}$ EDTA vials using the Sarstedt system by a paediatrician at Landspitali-University Hospital. This amount of blood was used to perform also other analyses than vitamin $C$ and $\beta$-carotene (12). In parents, venous blood samples were drawn on the same day as for their children using the Vacutainer $^{\mathrm{TM}}$ system using five $4 \mathrm{ml}$ serum gel vials, one $2 \mathrm{ml}$ EDTA vial and one $9 \mathrm{ml}$ EDTA vial. All samples were drawn in the morning after an overnight fast, and centrifuged for $10 \mathrm{~min}$ at $4^{\circ} \mathrm{C}$ within $30 \mathrm{~min}$ after the samples were drawn. The samples were protected from light, frozen immediately and transported on dry ice to Capio Diagnostik, Copenhagen, Denmark, where $\beta$-carotene was analysed by high-performance liquid chromatography after extraction (13), and vitamin C by photometry $(14,15)$.

\section{Intake measurements}

Three day weighed food records were used to assess the dietary intake of 6-year-old children. Parents or caregivers completed the children's diaries in terms of weighed grams. Parents' food intake was assessed using a validated semi-quantitative FFQ developed by the Icelandic Nutrition Council, including 130 different food items, reflecting food intake during the past 3 months (16). Quantities were estimated from photographs of four portion sizes of seven basic foods and from household measures. Results were scanned into a computer using a Hewlett Packard DeskScanII.

\section{Calculations and statistical analysis}

Nutrient calculations for the 3 day weighed record were performed using the NutriBase Clinical Nutrition Manager, version 4.71 (Cybersoft, AZ, USA, 2003). Foods and nutrients from the FFQ were calculated using the program ICEFOOD (Hugsja, Reykjavik). The program accounts for nutrient losses during food preparation and cooking. The Icelandic Nutrient Database (ISGEM) was used for the nutrient calculations on both occasions.

Statistical analyses were performed using SPSS for Windows version 11.0 (SPSS, Chicago, IL, USA). Means and standard deviations were used to describe the data. Serum $\beta$-carotene values were skewed and therefore log-transformed to reach normality, and these values were used for statistical analysis. Linear relationships between serum values were examined using Pearson's correlation coeffi- 
cient and the level of significance was taken as $p<$ 0.05 . Food items were not normally distributed and the relationship between family members' intake of fruit and vegetables, and the relationship between intake and serum concentration, were therefore assessed using Spearman correlation. Fruit and vegetable intake was also divided into quartiles for further analysis to minimize possible error due to the use of two different methods to assess dietary intake. Cross-tabulation together with a chi-squared test was used to assess, for example, the percentage of children with mothers in the highest quartile of vegetable intake who would fall into the highest and the adjacent quartile of vegetable intake, as well as the linear-by-linear association in intake.

Some of the participants, both children and parents, were reported to be taking supplements. All calculations were performed both with and without contributions from supplements.

\section{Results}

Table 1 shows the serum concentration of vitamin $C$ and $\beta$-carotene in children and their parents and Table 2 the correlations of these concentrations between family members. Table 3 shows the intake of vitamin $C$ and $\beta$-carotene as well as the intake of fruit and vegetables among children and their parents.

Table 2. Correlations of vitamin $C$ and $\beta$-carotene concentrations in serum between family members

\begin{tabular}{lll}
\hline & $\begin{array}{l}\text { Serum vitamin } C, \\
\text { child }\end{array}$ & $\begin{array}{l}\text { Serum vitamin } C, \\
\text { mother }\end{array}$ \\
\hline $\begin{array}{l}\text { Serum vitamin C, mother } \\
r\end{array}$ & 0.454 & \\
$P$ & $<0.001$ & \\
Serum vitamin C, father & & 0.570 \\
$r$ & 0.529 & 0.002 \\
$P$ & 0.002 & Log serum $\beta$-caro- \\
& Log serum $\beta$-caro- & tene, mother \\
& tene, child & \\
Log serum $\beta$-carotene, mother & & \\
$r$ & 0.385 & 0.497 \\
$P$ & 0.002 & 0.007 \\
$P$ & & \\
\hline
\end{tabular}

Table 3. Intake of vitamin C, $\beta$-carotene, fruit, vegetables, fruit juice and potatoes among 6-year-old children $(n=|3|)$, their mothers $(n=|| 2)$ and their fathers $(n=75)$

\begin{tabular}{|c|c|c|c|}
\hline & Mean $\pm S D$ & 10th \% & 90 th $\%$ \\
\hline \multicolumn{4}{|l|}{ Child } \\
\hline Fruit $\left(\mathrm{g}_{\text {day }}{ }^{-1}\right)$ & $78 \pm 68$ & 0 & 182 \\
\hline Vegetables (g day ${ }^{-1}$ ) & $26 \pm 68$ & 0 & 62 \\
\hline Potatoes $\left(\mathrm{g}_{\text {day }}{ }^{-1}\right)$ & $30 \pm 27$ & 0 & 61 \\
\hline Fruit juice $\left(\mathrm{g}_{\text {day }}{ }^{-1}\right)$ & $60 \pm 87$ & 0 & 200 \\
\hline Vitamin C, with supplements $\left(\mathrm{mg}\right.$ day $^{-1}$ ) & $78 \pm 69$ & 24 & 136 \\
\hline Vitamin C, without supplements ( $\mathrm{mg}$ day $^{-1}$ ) & $65 \pm 41$ & 22 & 130 \\
\hline$\beta$-Carotene, with supplements ( $\mu \mathrm{g}$ day $^{-1}$ ) & $741 \pm 1305$ & 160 & 1519 \\
\hline$\beta$-Carotene, without supplements ( $\mu \mathrm{g}$ day $^{-1}$ ) & $741 \pm 1305$ & 160 & 1519 \\
\hline \multicolumn{4}{|l|}{ Mother } \\
\hline Fruit $\left(\right.$ g day $\left.^{-1}\right)$ & $146 \pm 127$ & 48 & 286 \\
\hline Vegetables $\left(\mathrm{g}_{\text {day }}{ }^{-1}\right)$ & $74 \pm 50$ & 16 & 129 \\
\hline Potatoes $\left(\mathrm{g} \mathrm{day}^{-1}\right)$ & $82 \pm 57$ & 20 & 149 \\
\hline Fruit juice $\left(\mathrm{g} \mathrm{day}^{-1}\right)$ & $82 \pm 89$ & 2 & 243 \\
\hline Vitamin C, with supplements $\left(\mathrm{mg}\right.$ day $^{-1}$ ) & $212 \pm 187$ & 61 & 602 \\
\hline Vitamin $\mathrm{C}$, without supplements ( $\mathrm{mg}$ day $^{-1}$ ) & $92 \pm 47$ & 34 & $15 \mid$ \\
\hline$\beta$-Carotene, with supplements ( $\mu \mathrm{g}_{\text {day }}{ }^{-1}$ ) & $993 \pm 625$ & 420 & 1893 \\
\hline$\beta$-Carotene, without supplements ( $\mu g_{\text {day }}{ }^{-I}$ ) & $989 \pm 620$ & 421 & 1885 \\
\hline \multicolumn{4}{|l|}{ Father } \\
\hline Fruit $\left(\mathrm{g}_{\text {day }}{ }^{-1}\right)$ & $94 \pm 70$ & 20 & 205 \\
\hline Vegetables (g day ${ }^{-\mathrm{I}}$ ) & $53 \pm 46$ & 8 & 99 \\
\hline Potatoes $\left(\mathrm{g} \mathrm{day}^{-1}\right)$ & $104 \pm 89$ & 13 & 210 \\
\hline Fruit juice $\left(\mathrm{g}_{\text {day }}{ }^{-1}\right)$ & $92 \pm 122$ & 0 & 250 \\
\hline Vitamin C, with supplements $\left(\mathrm{mg}_{\mathrm{day}}{ }^{-1}\right.$ ) & $124 \pm 110$ & 34 & 263 \\
\hline Vitamin C, without supplements ( $\mathrm{mg} \mathrm{day}^{-1}$ ) & $80 \pm 50$ & 26 & 155 \\
\hline$\beta$-Carotene, with supplements ( $\mu \mathrm{g}_{\text {day }}{ }^{-1}$ ) & $879 \pm 611$ & 382 & $135 \mid$ \\
\hline$\beta$-Carotene, without supplements $\left(\mu \mathrm{g}\right.$ day $^{-1}$ ) & $825 \pm 396$ & 382 & 1333 \\
\hline
\end{tabular}

Seven children (5\%) were using liquid multivitamin formula giving $60 \mathrm{mg}$ vitamin $\mathrm{C}$ per $10 \mathrm{ml}$, which is the suggested daily dose; 67 mothers $(60 \%)$ and 22 fathers (29\%) were using supplements.

\section{Plasma concentrations}

The mean serum concentration of vitamin $\mathrm{C}$ ranged from 55 to $74 \mu \mathrm{mol}^{-1}$ and that of $\beta$-carotene from 0.3 to $0.5 \mu \mathrm{mol}^{-1}$ (Table 1 ). There was a positive correlation between serum vitamin $\mathrm{C}$ concentration in children and their parents as well as between the parents. Serum $\beta$-carotene concentration also correlated positively between family members. The correlation coefficients are shown in Table 2. To obtain a measure of how much of the variability in one variable could be explained by variation in another, correlations were squared. A correlation coefficient of $0.385-0.570$ (range in Table 2) squared is about $0.15-0.32$. Therefore, about $15-$ $32 \%$ of the variability in children's serum concentration could be explained by differences in the parents' serum concentration. 


\section{Fruit and vegetable intake}

Consumption of fruit, vegetables and fruit juice was on average $194 \pm 126,384 \pm 181$ and $343 \pm 189 \mathrm{~g}$ day $^{-1}$ for the children, mothers and fathers, respectively (Table 3 ). The mean intake of potatoes is also given in Table 3, because potatoes may provide substantial amounts of vitamin $\mathrm{C}$, at least for the fathers, who had a mean intake above $100 \mathrm{~g}$ day $^{-1}$. Intake of fresh fruit, fruit juice and green leafy vegetables correlated positively between family members $(r=0.227, p<0.05$ and $r=0.313, p<0.01$ between children and their mother and father, respectively, and $r=0.247, p<0.05$ between parents). By dividing vegetable intake into quartiles and using cross-tabulation, it could be seen that $58 \%$ of the 6 -year-olds whose mothers were in the lowest quartile of vegetable intake fell into the lowest or adjacent quartile of vegetable intake. At the other end, $67 \%$ of children with mothers in the highest quartile of vegetable intake had intake that fell into the highest or second highest quartile of vegetable intake among children. The linear-bylinear association was significant $(p<0.01)$. Corresponding figures relating children's vegetable intake to that of their father were $75 \%$ at the lower end and $72 \%$ at the higher end, and the linear-by-linear association was significant $(p<0.05)$.

\section{Vitamin $C$ and $\beta$-carotene intake}

A positive correlation was also seen between maternal and children's vitamin $\mathrm{C}$ intake without supplements $(r=0.284, p<0.01)$, and between fathers and children's intake $(r=0.375, p<0.001)$. No association was found between children's and parents' vitamin $\mathrm{C}$ intake when the analysis was performed including supplement use by parents. Mothers' and fathers' vitamin $\mathrm{C}$ intake with $(r=$ $0.546, p<0.001)$ and without $(r=0.258, p<0.05)$ supplements also correlated, whereas no correlation was seen between the family members' $\beta$-carotene intakes. There was a positive correlation between children's vitamin $\mathrm{C}$ intake without supplements and their serum vitamin $\mathrm{C}(r=0.288, p<0.05)$, but not when analysed including supplements. Children's intake of $\beta$-carotene correlated with their serum $\beta$-carotene concentration $(r=0.315, \quad p<$ 0.01 ). Results for the association between the parents' intake and their serum concentration have been shown previously (16).

\section{Discussion}

The present study shows an association between children's and their parents' serum values of nutrients commonly used as markers of fruit and vegetable intake. The study is the first Icelandic dietary study on 6-year-old children in relation to intake by their parents. The study supports an association seen in other studies between fruit and vegetable or nutrient intake between children and parents $(17,18)$. A novel finding is that 6 -year-old children's intake of fresh fruit, fruit juice and vegetables seems to be more related to that of their father than their mother.

There was a positive correlation between fruit and vegetable as well as vitamin $\mathrm{C}$ intake by the children and the intake by both of their parents. The correlation between parents; and children's intakes indicates that the parents' fruit and vegetable intake may encourage fruit and vegetable intake in their children. Fisher et al. (18) reported that parents' fruit and vegetable intake might encourage fruit and vegetable intake in their daughters. An interesting positive association was seen in the present study between mothers' and fathers' vitamin $\mathrm{C}$ intake, indicating a routine in the families regarding fruit and vegetable consumption.

The results highlight the importance of familybased intervention aiming at fruit and vegetable intake. Further, this study suggests that it is important that the father is included in the intervention programme, not only the mother. The correlation between serum vitamin $\mathrm{C}$ and dietary vitamin $\mathrm{C}$ intake for an adult individual has been seen elsewhere $(4,5)$, but the correlation of serum concentration between family members has not been shown previously. Childhood fruit consumption is an important subject as it may have a longterm protective effect against cancer risk in adults (19). The present study investigated children at 6 years of age, the age when school begins, because this is an important milestone in life where dietary intervention programmes could be of importance. Food habits are often established in childhood and tend to be maintained into adulthood $(20,21)$. Children's food choices are shaped by individual and societal factors and therefore parents and caregivers play an important role in influencing what children eat (22).

The average intake in the present study of fruit and vegetables among 6-year-old children and their parents was lower than the WHO population goal 
of $400 \mathrm{~g}$ of fruit and vegetables per day for adults (8). It does not specify whether fruit juice should be included. The Icelandic recommendation is $>200 \mathrm{~g}$ fruit and $>200 \mathrm{~g}$ vegetables per day, or $>500 \mathrm{~g}$ per day if fruit juice is included (9). Only $30 \%$ of mothers and $10 \%$ of fathers consumed more than $200 \mathrm{~g}$ of fruit daily. The intake of vegetables was exceptionally low, with only two mothers and one father consuming the recommended amount of $>200 \mathrm{~g} \mathrm{day}^{-1}$. Although the consumption of fruit and vegetables is much lower than the recommended intake, the average intake has been increasing over the past few decades among adults in Iceland (9). A recommended intake for children has not been established (23), but a lower intake than recommended for adults could be acceptable for 6year-old children because of their lower energy intake.

The association of vitamin $\mathrm{C}$ intake between family members was assessed both excluding and including dietary supplements. The lack of association between children's and their parents' intake when supplements were included is likely to be due to relatively high doses used by some of the parents, whereas very few children were found to use supplements.

Serum vitamin $\mathrm{C}$ reflects recent intake of the vitamin (24), and thus a single serum vitamin C measurement, as used in the present study, could misclassify many individuals with respect to their long-term intake (25). However, in the present study blood samples were obtained from children and parents on the same day, so their serum levels would be expected to reflect the intake during same period for both parents and children. It could also be expected that changes in the dietary habits of parents would also cause changes in the children's habits.

Increased intake of fruit and vegetables has been shown to reduce the risk of several diseases (1-3) and the protective effects are suggested to be due mainly to antioxidants. During the past few years, school-based studies focusing specifically on fruit have been published. A study in Minnesota, USA, demonstrated a significant increase in observed lunchroom intake of fruit and vegetables, and an overall increase in reported fruit consumption, but not vegetable consumption, among fourth and fifth graders (26). Similarly, a 14\% increase in the usual daily servings of vegetables and fruit was observed for a high-school programme, but this effect disappeared by year 3 (27).

Although no long-term studies on children's consumption of fruit and vegetables or their serum antioxidant status have been performed, it may be assumed that a high concentration of antioxidants in children's blood could be important in reducing the risk of cancer and cardiovascular disease later in life. Several intervention studies have been performed to increase consumption of these products. Steptoe et al. reported that brief interventions could be effective in increasing consumption of fruit and vegetables (28). According to their results, intervention early in life and by the family is worth investigating. The present study supports this view. Future studies need to focus on specific eating behaviours related to fruit and vegetable consumption.

In conclusion, the relationship between children's and their parents' fruit and vegetable intake is supported in the present study by an even stronger correlation between family members in serum concentrations of vitamin $\mathrm{C}$ and $\beta$-carotene. Interventions aimed at increasing fruit and vegetable consumption by children should focus on the whole family.

\section{Acknowledgements}

This study was supported by a research grant to Inga Thorsdottir from the Icelandic Research Council, Research Fund of the University of Iceland, the Icelandic Ministry of Agriculture, Dairy Marketing Board and Dairy and Beef Farmers' Association, and to Ingibjörg Gunnarsdottir from the Fund for Research Training and Graduate Education.

\section{References}

1. World Health Organization. Global strategy on diet, physical activity and health. Geneva: WHO; 2004.

2. Nutrition and diet for healthy lifestyles in Europe: science and policy implications. Proceedings of the European Conference, May 18-20, 2000, Crete, Greece. Public Health Nutr 2001;4:337-434.

3. $\mathrm{Hu} \mathrm{FB}$, Willet WC. Optimal diets for prevention of coronary heart disease. JAMA 2002; 288: 2569-78.

4. Zino S, Skeaff M, Williams S, Mann J. Randomised controlled trial of effect of fruit and vegetable consumption on plasma concentrations of lipids and antioxidants. BMJ 1997; 314: 1787.

5. Ness AR, Khaw KT, Bingham S, Day NE. Plasma vitamin C: what does it measure? Public Health Nutr 1999; 2 : $51-4$. 
6. Palli D, Decarli A, Russo A, Cipriani F, Giacosa A, Amadori D, et al. Serum levels of antioxidant vitamins and cholesterol in a large population sample in centralnorthern Italy. Eur J Nutr 1999; 38: 90-8.

7. Hercberg S, Galan P, Preziosi P, Alfarez MJ, Vazquez C. The potential role of antioxidant vitamins in preventing cardiovascular diseases and cancers. Nutrition 1998; 14: 513-20.

8. World Health Organization. Diet, nutrition and the prevention of chronic diseases. Geneva: WHO; 2003.

9. Steingrimsdottir L, Thorgeirsdottir H, Olafsdottir AS. The diet of Icelanders. Dietary survey of the Icelandic Nutrition Council 2002. Main findings. Reykjavik: Icelandic Nutrition Council; 2003.

10. Gunnarsdottir I, Thorsdottir I. Relationship between growth and feeding in infancy and body mass index at the age of 6 years. Int J Obes Relat Metab Disord 2003; 27: $1523-7$.

11. Gunnarsson BS, Thorsdottir I, Palsson G. Iron status in 2-year-old Icelandic children and associations with dietary intake and growth. Eur J Clin Nutr 2004; 58: 901-6.

12. Thorsdottir I, Gunnarsdottir I, Palsson GI. Association of birth weight and breast-feeding with coronary heart disease risk factors at the age of 6 years. Nutr Metab Cardiovasc Dis 2003; 13: 267-72.

13. Thurnham DI, Smith E, Flora PS. Concurrent liquidchromatographic assay of retinol, alpha-tocopherol, beta-carotene, alpha-carotene, lycopene, and beta-cryptoxanthin in plasma, with tocopherol acetate as internal standard. Clin Chem 1988; 34: 377-81.

14. Ordell R. Ascorbinsyra. Chem Analyst 1961;64-68.

15. Estelle R, Lench H, Lewis GT. Determination of ascorbic acid in blood. Chem Analyst 1961;50:18-19.

16. Thorsdottir I, Gunnarsdottir I, Steingrimsdottir L. Validity of a food frequency questionnaire to assess dietary intake of adults. Icelandic Medical Journal 2004; 90: $37-41$.

17. Birch LL, Fisher JO. Development of eating behaviors among children and adolescents. Pediatrics 1998; 101: $539-49$.

18. Fisher JO, Mitchell DC, Smiciklas-Wright H, Birch LL. Parental influences on young girls' fruit and vegetable, micronutrient, and fat intakes. J Am Diet Assoc 2002; 102: 58-64.

19. Maynard M, Gunnell D, Emmett P, Frankel S, Davey SG. Fruit, vegetables, and antioxidants in childhood and risk of a cancer: the Boyd Orr cohort. J Epidemiol Community Health 2003; 57: 218-25.

20. Kelder SH, Perry CL, Klepp KI, Lytle LL. Longitudinal tracking of adolescent smoking, physical activity and food choice behaviors. Am J Public Health 1994; 84: 1121-6.

21. Caius N, Benefice E. Food habits, physical activity and overweight among adolescents. Rev Epidemiol Sante Publique 2002; 50: 531-42.

22. Puhl RM, Schwartz MB. If you are good you can have a cookie: how memories of childhood food rules link to adult eating behaviors. Eating Behaviors 2003; 4: 28393.

23. Nordic Nutrition Recommendations 2004. Integrating nutrition and physical activity. 4th edn. Copenhagen: Nordic Council of Ministers; 2004.

24. Jacob RA, Skala JH, Omaye ST. Biochemical indices of human vitamin C status. Am J Clin Nutr 1987; 46: 818 26 .

25. Willett W. Nutritional epidemiology, 2nd edn. New York: Oxford University Press; 1998.

26. Perry CL, Bishop DB, Taylor G, Murray DM, Mays RW, Dudovitz BS, et al. Changing fruit and vegetable consumption among children: the 5-a-Day Power Plus program in St. Paul, Minnesota. Am J Public Health 1998; 88: 603-9.

27. Nicklas TA, Johnson CC, Myers L, Farris RP, Cunningham A. Outcomes of a high school program to increase fruit and vegetable consumption: Gimme 5 - a fresh nutrition concept for students. J Sch Health 1998; 68: 248-53.

28. Steptoe A, Perkins-Porras L, McKay C, Rink E, Hilton $\mathrm{S}$, Cappuccio FP. Behavioural counselling to increase consumption of fruit and vegetables in low income adults: randomised trial. BMJ 2003; 326: 855.

\footnotetext{
Inga Thorsdottir

Unit for Nutrition Research

Landspitali-University Hospital

IS- I0I Reykjavik

Iceland

Tel: + $3545438416 / 8410$

Fax: + 3545434824

E-mail: ingathor@landspitali.is
} 